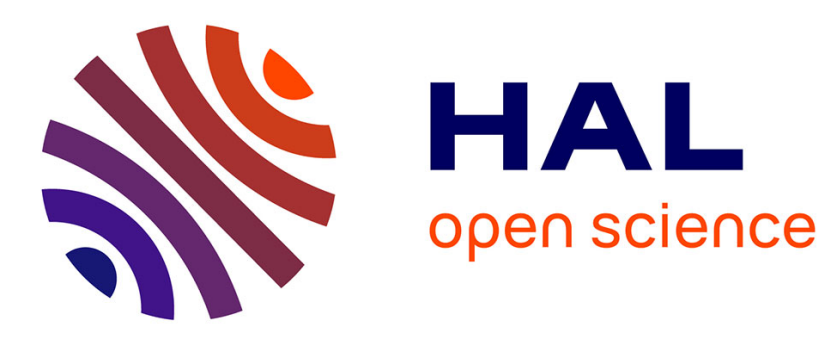

\title{
Laser induced mechanical effects in biomaterials
}

\author{
G. Delacrétaz, K. Rink, T. Asshauer
}

\section{To cite this version:}

G. Delacrétaz, K. Rink, T. Asshauer. Laser induced mechanical effects in biomaterials. Journal de Physique IV Proceedings, 1994, 04 (C4), pp.C4-269-C4-269. 10.1051/jp4:1994462 . jpa-00252725

\section{HAL Id: jpa-00252725 https://hal.science/jpa-00252725}

Submitted on 1 Jan 1994

HAL is a multi-disciplinary open access archive for the deposit and dissemination of scientific research documents, whether they are published or not. The documents may come from teaching and research institutions in France or abroad, or from public or private research centers.
L'archive ouverte pluridisciplinaire HAL, est destinée au dépôt et à la diffusion de documents scientifiques de niveau recherche, publiés ou non, émanant des établissements d'enseignement et de recherche français ou étrangers, des laboratoires publics ou privés. 


\title{
Laser induced mechanical effects in biomaterials
}

\author{
G. DELACRÉTAZ, K. RINK and T. ASSHAUER
}

Laboratoire d'Optique Appliquée, Ecole Polytechnique Fédérale de Lausanne, 1015 Lausanne, Switzerland

Mechanical effects induced by lasers with nanoseconds to hundreds of microseconds pulse duration on biomaterials are discussed. Strong shock waves are generally observed during laser irradiation due to very rapid beating and phase change in the interaction zone. Moreover even stronger shock waves can be generated some hundreds of microseconds later in response to the collapse of the induced cavitation bubble in confined environment. The impact of the laser induced cavitation processes on the observed damage on selected biotargets (bone, cartilage and urinary stones) will be discussed. The effect of the laser pulse characteristics on both acoustical transients will be discussed as well. 